\title{
The Track of History: Finance and National Governance in Ancient China
}

\author{
Jierui $\mathrm{Jia}^{1,2}$, Junyang $\mathrm{Li}^{3}$, $\mathrm{Ke} \mathrm{Gao}^{3,4}$ \\ ${ }^{1}$ School of Public Finance and Tax, Central University of Finance and Economics, Beijing, P. R. China \\ ${ }^{2}$ School of Public Finance and Tax, Henan University of Economics and Law, Zhengzhou, P. R. China \\ ${ }^{3}$ International Ecological Economy Promotion Association, Beijing, P. R. China \\ ${ }^{4}$ School of Business and Administration, Xinjiang University of Finance and Economics, Wulumuqi, P. R. China
}

\section{Email address:}

1743131519@qq.com (Jierui Jia),junyang.li@ieepa.org.cn (Junyang Li),gkfly@126.com (Ke Gao)

\section{To cite this article:}

Jierui Jia, Junyang Li, Ke Gao. The Track of History: Finance and National Governance in Ancient China. International Journal of Education, Culture and Society. Vol. 4, No. 1, 2019, pp. 13-18. doi: 10.11648/j.ijecs.20190401.12

Received: February 11, 2019; Accepted: April 18, 2019; Published: April 28, 2019

\begin{abstract}
Finance was an old category. Finance emerged as a result of the emergence of the human community and public needs. Ancient Chinese finance included the thought of loving the people, and also had a complete system of budget, tax, social security, financial management and supervision. These systems were conducive to the allocation of resources, the development of public economy, the circulation of commodities and the fight against usury. Finance is a comprehensive category across political, economic, legal, social, cultural and military fields, and an important tool for national governance. In many historical periods, fiscal reform was the forerunner of social reform. But ancient Chinese finance developed in a highly centralized environment. The supremacy of the imperial power led to the obvious characteristic of "the rule by man". The corruption of the feudalistic bureaucratic system led to the implementation deviation of fiscal policy. The totalitarian system led to the imbalance between intergovernmental relations. Contemporary China should establish a modern fiscal and taxation system that is in line with the requirements of the market economy, handle the relations between the central government and local governments properly, and encourage citizens to participate extensively in the reform of the country.
\end{abstract}

Keywords: Ancient finance, National Governance, Macro Control, Fiscal Reform

\section{Introduction}

"Governance" appeared early in Latin and Greek. "Governance" is not "government". Governance embodies the meanings of process, coordination, publicity, interaction and pluralism. Finance was also an old category. China's ancient finance had always been paying attention to the relationship between the state and the people in the implementation. Its mechanism design hadalso made it become the foundation and pillars of the development for many political, economic, social and cultural undertakings. Finance was the foundation and important pillar of national governance. Ancient China's finance had a complete system design, such as budget, tax, financial management and social security. These systems were conducive to the allocation of resources, the development of public economy, the circulation of commodities and the fight against usury. These systems had strongly promoted the process of national governance. Therefore, in many historical periods, fiscal reform was the forerunner of social reform. Of course, ancient Chinese finance developed in a highly centralized environment. From a modern point of view, many factors restricted the transformation of ancient Chinese finance to modernization. Therefore, taking the past as a lesson, we should find a right way of financial reform in contemporary China.

\section{Literature Review}

Many scholars have discussed this proposition. Gao Peiyong (2014) believed that the proposition clarified the essence of finance, clarified the relationship between fiscal and taxation reform and the overall reform of the country, and was a major breakthrough in the basic theory of finance. 
[1] Li Weiguang (2014) believed that finance was the medium connecting politics, economy and society. Contemporary China should build a modern financial system. [2] Liu Shangxi (2015) believed that in the implementation of national governance, fiscal activities and fiscal reform should strive to achieve the goals of "efficiency", "fairness", "moderation" and "inclusiveness". [3] Liu Xiaolu and GuoQingwang $(2016,2017)$ carried out a series of studies, discussed the characteristics of the development of Finance in different stages, discussed the impact of the concept of national governance on finance, and put forward the concept of "national governance finance". [4, 5] Some scholars put forward specific and operable suggestions, such as Bai Yanfeng and Zhang Jing (2016), to explore how to improve the ability of national governance in the areas of budget system, tax system and intergovernmental financial relations. [6] Some scholars have re-examined the western financial thought, such as Ma Jun (2016) who studied Buchanan's financial thought, thus studying the relationship between finance and national governance. [7] Some scholars try to study financial problems from a historical perspective. For example, Shi Wei (2015) believed that ancient Chinese finance had many characteristics of modern finance, but ancient Chinese finance was restricted by various factors and could not enter modernization. [8] Many scholars have studied the relationship between finance and national governance from a modern perspective, lacking a deep understanding of this relationship from a historical perspective. This paper attempts to summarize the financial practice and thought of ancient China, and prove that finance has played an important role in national governance since ancient times.

\section{Finance Had Been "The Mother of All Government Affairs" Since Ancient Times}

\subsection{Finance Was an Old Category}

As the mother of general affairs and the basic economic system of the state, finance was very important in promoting the transformation of the mode of economic development. Finance was an old category. Finance was born out of the "public needs" of the human community, so finance emerged with the early evolution of human society. The material conditions of finance generating were the development of productivity and the emergence of surplus products, and public allocation was also emerged so as to meet the needs of social and public affairs. The social conditions of finance generating were that needs for social and public management and some individuals who were dedicated to public management emerge with the development of social division of labor. The political conditions of finance generating were that country and national institutional system emerge with the establishment of private ownership and the intensification of class differentiation. [9] Finance in ancient China assumed the role of maintaining the functioning of the country and social public functions.

\subsection{The Thoughts of Finance in Ancient China Were Rich in the Contents of Understanding and Sympathizing with the People}

China's ancient wise men had rich thoughts of compensating the people while dealing with the financial relationship between the country and the people. Guan Zhong in the Spring and Autumn Period believed that there should be a limitation while taking from people, the expropriation and collection of the country from the people should be within limits. Confucius in the Spring and Autumn Period believed that "the benevolent loves others", who also advocated reduce the expropriation and collection. Fan Zhongyan submitted a written statement to Emperor Renzong of Song in the Song Dynasty, and he suggested that the rulers should "attach importance to agriculture" and "love the people". [10] All these wise men had recognized that the monarch should understand and sympathize with people's affordability, reduce the burden of taxation of taxation and cost, and ensurethat the people lived happily with good heavy food in the house. Only in this way would the people be convinced by the monarch. Only when the people trust the country could the political affairs of the country be done well and could the financial resources of the country be guaranteed.

\subsection{Finance in Ancient China Had a Complete Institutional Design}

\subsubsection{Budget System}

More standardized budgetary ideas had emerged during the pre-Qin period. It was recorded in Rites of Zhou that fiscal revenue and fiscal expenditure should be corresponding to each other. This had already become a more standardized budget. "Royal finance" and "national finance" were separated during the Qin and Han Dynasties, and each had its own source of income and range of expenditure, which made the budget system more standardized and effective. It was stipulated in the Han Dynasty that local governments should periodically report the financial revenue and expenditure to the central government, and also formulated the budgetary principles that tax revenue was determined according to needs of national public affairs and administrative management. [11] The budgetary method similar to the Re-examination budget was adopted in the Tang Dynasty of China, and the whole process of budget's compilation, review, issuance, execution and performance audit was legally stipulated. Therefore, the state budget system was an important means of the reign over the successive dynasties.

\subsubsection{Taxation System}

China's initial tax form was "Gong", it was the ruler who levied native products and agricultural products from the liegemen. "Fu" and "tax" emerged later, "Fu" was to collect military service and military supplies according to the population, and "tax" was to levy property for land and 
business. The process of land privatization was accelerated during the Spring and Autumn period, "initial tax on land per mu" emerged that collecting taxes according to the number of $\mathrm{mu}$, the country began to tax on the numbers of mu, therefore, agricultural land tax had become an important source of fiscal revenue in ancient China. [12] In addition, China's government had also forced the people to perform military service and forced labour. Corvee was also an important form of revenue for China's ancient finances. After the Ming and Qing Dynasties, China's land tax and corvee had been basically combined. Therefore, taxation was an important tool for the macro-control and maintenance of operation in ancient China.

\subsubsection{Social Security System}

China had generated primitive ideas of social security 2000 years ago. It was suggested in the Book of Rites that the goal of the pantisocracy was to enable the old to be hospice, the young people to support themselves, the young children to thrive, and the disabled to be supported. Many dynasties in ancient China had carried out the practice of social security, for example, a number of social security projects were in the fiscal expenditure of the Han Dynasty such as raising orphans, helping widowers and widows, and relieving famine, etc. The government of the Tang Dynasty ever set up institutions such as the place for people with major illnesses, a place for the elderly to retire without children or companions, etc. The Song Dynasty government ever set up such institutions as "Fu Tian Garden", "Baby Bureau" and "Ci You Bureau". The Ming government ever set up the granary for disaster preparedness and formulated a standardized disaster early warning mechanism and the system of supporting the old. [13] These were all used for social security. Social security can resolve the contradictions of society and reduce the hidden dangers of social riots. It was the regulator to ensure the smooth operation of the country.

\subsubsection{Financial Management and Supervision System}

China's ancient financial institutions had a well-organized division of labor and each performed its own functions. It was recorded in Rites of Zhou that the country's financial management institutions were "DaFu", "Zai Shi", "SiKuai", "ChanRen", etc. The financial management institutions included "ShaoFu" and "ZhisuNeishi" during the Qin and Han Dynasties. The Tang, Song, Ming and Qing dynasties all had "the Ministry of Revenue" to manage the country's financial matters. In addition, ancient China attached great importance to managing finances in the form of digitization. As proposed in "Rites of Zhou" local governments should report statistical data by time nodes, which would serve as the basis for governing the country and finance after analyzed by the central government. Liu Yan of the Tang Dynasty set up the specialized agency named "Xun Yuan" in each local area, and extensively collected data from all over the country, which would be easy for the country to make decisions. There was also a strict system of fiscal supervision in ancient China. Many dynasties had special supervisory organs. For example, special official posts named "Bi Bu" and "Yu Shi" were set up in the Tang Dynasty, and special official posts institutions named "Duchayuan" and "Qinglishi" were set up in the Ming and Qing Dynasty. [14] They were all responsible for financial supervision. The complete system of financial management and supervision enhanced the sustainability and standardization of finances, which was conducive to the country to gather wealth and safeguard the public interest.

\section{The Mechanism Design of China's Ancient Finance Was Beneficial to the National Macro-Control}

\subsection{Budget and Taxation Systems Could Promote Resource Allocation}

The budget system in ancient China involves financial, military and political power, so monarchs of various dynasties had attached great importance to strengthening centralization through budgetary mechanisms. The budget regulated the allocation of social resources in various sectors through the planning and arrangements for social wealth, and the operation of the budget comprehensively reflected the overall picture of the political, economic and cultural undertakings of a dynasty. Similarly, taxation was also the allocation of material wealth. The country collects property from the private sphere through the tax system, and then these properties were purposely applied to the aspects of social development, public works, cultural education and others through the means of public distribution. Efficient taxation system could promote the development of various undertakings in the country. The tax system could also regulate the economic interest relationship between the various subjects of the country. Some dynasties redistributed economic interests through tax reforms, which could alleviate the contradiction between the vested interests and the underlying masses in the society and promote national stability of the country and social harmony. [15]

\subsection{The National Monopoly System Could Develop the Public Economy}

National monopoly referred that the country occupied a certain social resource by virtue of political power, and carried out the monopoly management of it. In ancient China, the goods implementing the country monopoly were generally the goods and materials related to the national economy and the livelihood such as salt, iron, tea, wine, vinegar, etc. National monopoly was an important way for the country to acquire wealth, which was also an important means for the country to regulate the economy. Guan Zhong in the Spring and Autumn Period firstly put forward the "Guan Shan Hai (charging all the natural resources)". It was hoped to increase the country's fiscal revenue without increasing taxes. Shang Yang in Qin Dynasty also ever implemented a similar national monopoly system, through 
which to combat the power of the wealthy merchants, thus urging people to focus on agriculture. Sang Hongyang in the Western Han Dynasty promoted the measures of national monopoly, which not only hit the political power of the salt and iron merchants, but also eliminated the material basis of the princes setting up a separatist regime by force of arms. Liu Yan in the Tang Dynasty established the system of salt tax and salt monopoly, which not only encouraged the enthusiasm of salt farmer families and merchants, but also played the role of the country in regulating the economic field and people's lives.

\subsection{Pingzhun Policy Could Regulate the Circulation of Commodities}

Pingzhun policy was an important means for the countries in ancient times to regulate the supply and demand relations and stabilize commodity prices of the market. Guan Zhong in the Spring and Autumn Period believed that food and currency are special items, and they should be used to adjust the price of other goods. Sang Hongyang in the Western Han Dynasty set up a stabilized agency in Chang'an. The principle of the stabilized agency was sold it if it was expensive and then buy it if it was cheap. By buying and selling commodities, the country stabilized prices and thus increased fiscal revenue. Wang Anshi in the Northern Song Dynasty implemented "Shi Yi Fa (Law for market transactions)"and set up specialized agencies named "Shiyiwu" (agents serving for market transactions). [16] Through this institution, the country bought and sold some important commodities in order to regulate the supply of commodities, stabilize prices and increase fiscal revenue. Pingzhun policy reflected the idea that the country carries out economic management by following the law of value.

\subsection{The Fiscal Credit System Could Combat Private Usury}

Fiscal credit was the way that the country regulated economy by the means of credit. During the Western Zhou dynasty in China, an institution called "Quan Fu" was an official institution specialized in fiscal credit. Guan Zhong suggested the state to lend money to farmers with good farming performance, enabling them to expand reproduction. At the end of the Western Han Dynasty, Wang Mang stipulated in his reform that the common people could apply to the government for loans used for agricultural production, and such loans had long maturities and low interest rates, which could boycott the harm of private usurious loans. In the Northern Song Dynasty, Wang Anshi promoted the Law of Young Crops during his reform, which stipulated that the local government could lend money to farmers every year when there was a temporary shortage of crops, and farmers should repay the money with the taxes of summer and autumn. Sometimes, this measure was much too demanding, but to some extent it had played a role in preventing the infringement of usurious loans and protecting the farmers' interests.

\section{Finance in Ancient China Is the Forerunner of National Reform}

\subsection{The Nature of Finance Determined the Function of Finance in Reform}

The fiscal mechanism had rich connotation, including budget, taxation, government debt, social security, fiscal expenditure, financial supervision and management and other systems. The research objects of finance were extensive and intensive, including the basic law of financial operation, the fiscal relationship between governments, digital management technology, the allocation of financial resources and so on. Finance was a comprehensive category spanning politic, economy, laws, society, culture and military affairs and other fields. It was a link that connected various causes. To properly handle the fiscal relationship between the country and the people was conducive to promoting the development of productivity, increasing social wealth, promoting social equity, mitigating social conflicts and achieving long-term peace and stability of the country. Therefore, it was determined by the basic nature of finance that finance played a fundamental and pillar role in the cause of national governance and was the forerunner of national reform.

\subsection{The Practices of Fiscal and Taxation Reforms in Ancient China}

\subsubsection{The Urgency of Reform}

Some important fiscal and taxation reforms in ancient China were carried out under the circumstances of the contradiction between productive relations and productivity. At this time, the contradictions in the political, economic, social and cultural fields of the country were acute, so the country had to carry out reforms. For example, in the Warring States Period, the Qin State fell behind other oriental states and was despised by all the states in the Central Plains. The Qin State was in great risk of being annexed. The monarch of Qin named "Qinxiaogong” drew a lesson from the bitter experience and decided to appoint Shang Yang as "ZuoShu Zhang" to start a reform. As another example, at the beginning of the Northern Wei Dynasty, on the one hand, the Central Plains suffered turmoil, resulting in the reduction of most population and the crash of social economy. On the other hand, Xianbei Nobles and landlords of Han Nationality wantonly annexed the land, resulting in a large number of refugees and tenant farmers. Facing the prominent social contradictions, the government of the Northern Wei Dynasty had to reform. In 485, Emperor Xiaowen began to implement the reform of "Juntian system", "Sanzhang System" and "new Zudiao System" so as to consolidate the political power. [17].

\subsubsection{The Far-Reaching Impact of Reforms}

The major fiscal and taxation reforms in ancient China were not only fruitful at that time, but also had far-reaching impact on future generations. For example, after Shang Yang's reform, the productivity of the Qin State increased dramatically, and 
lots of land were developed. The people were rich and the state was powerful, which laid a solid material foundation for the Qin State to rule all the land. Besides, the basic systems established by Shang Yang's reform also exerted influence on Chinese autocratic monarchy for over two thousand years. [18] As another example, the reform of Emperor Xiaowen in the Northern Wei Dynasty combined the labor force with land, rationalized the taxation system, and coordinated the relationship between tax collection and tax payment. Therefore, it was recorded in the historical records that after the reform of Emperor Xiaowen, there were no enemy daring to harass the country and the country was rich and the people were healthy. Furthermore, the taxation system of the Northern Wei Dynasty was implemented continuously in the Northern Qi Dynasty, Northern Zhou Dynasty, Sui Dynasty and Tang Dynasty until the enactment of the Double-tax Law in the midterm of the Tang Dynasty that these systems were abolished. The impact of these systems lasted for over 300 years.

\subsubsection{The Consistency of the Reform Objectives}

Many major fiscal and taxation reforms in ancient China had reflected a relatively consistent concept of national governance. The first was to coordinate the relationship between tax collection and tax payment. For example, the government of the Han Dynasty learned lessons from the demise of the Qin Dynasty, reduced the taxation and corvee, and allowed the people to relax and reduced the rate of feudal land tax to one thirtieth. The government gave the people space to relax, thus the people took delight in production so that they could pay sufficient taxes to the state. The second was to narrow the gap between the rich and the poor through fair taxation. For example, in the midterm of the Tang Dynasty, it was stipulated in the Double-tax Law that the miscellaneous collection of taxes and corvee were abolished and that people could pay their taxes according to the land and properties they possessed. Tax collection in this way reflected the fairness and justice of taxation and promoted the fairness and justice of the society. The third was to promote social production and increase national wealth. For example, in the Northern Song Dynasty, the political reform of Wang Anshi reduced the bondage of farmers and increased agricultural production by adopting the Law of Corvee Exemption, and he sorted out the cadastral data and increased the farmland taxed for the feudal state by adopting the Measures named "Fangtian Junshui". Through the reform, the national strength of the Northern Song Dynasty had increased dramatically, and the money accumulated by the central government could support the expenditure of the state for 20 years. [19]

\section{On the Defects of Chinese Ancient Finance in National Governance from the Modern Perspective}

Ancient China's finance developed in a long-term autocratic monarchy and a high centralization. The supremacy of imperial power and the decadence of the feudal bureaucratic system had restricted the process of China's financial modernization. Contemporary China should sum up and reflect on the experience and lessons of ancient financial practice and establish a modern financial system adapted to the socialist market economy.

\subsection{The Fundamental Characteristic of Finance in Ancient China Was "Rule of Man"}

Ancient China had long been under autocratic monarchy and highly centralized power, and imperial power transcended all laws and systems. In ancient China, the feudal bureaucratic groups gradually separated from the people and became an affiliated part of the imperial power. Bureaucracy had become a privileged class, and they could escape the restrictions of national laws and regulations. Bureaucratic fraud in disaster relief, state monopoly, water transport, taxation and other key areas had weakened the function of financial accumulation and regulation. In china, there was no God, Confucians thus held that men ought to be ruled by men. China had experienced thousands of years of feudal society ruled by men, in which some people had a weak sense of legality. In the modern society, the rule of god, the rule of morality and the rule of man have all gradually lost their basis, while the rule of law have become the main method for administering a country. Therefore, the financial activities of ancient China lacked the participation of the broad masses of people. Ancient China was very arbitrary in formulating fiscal policies. Throughout the rise and fall of Chinese dynasties, rulers were merciful to the people at the beginning of their rule, unprogressive at the middle of their rule, luxurious and extravagant at the end of their rule, and finally subjugated their country.

\subsection{The Relationship Between Central Government and Local Government in Ancient China Was Unbalanced}

In ancient China, only at the end of some dynasties or during the period of great national split did the financial system become decentralized. But this was not the true sense of central and local fiscal decentralization, nor was it the normal history. Ancient China's finance often embodied strong centralization. For example, in the Song Dynasty, local incomes were sent to the capital in addition to basic expenses. Local governments had little financial power. During the Ming and Qing Dynasties, although the feudal state had local financial management agencies, local governments had no financial rights. They collected and spent on time according to the instructions of the central government, and all the balance of revenue and expenditure was turned over to the central government. Therefore, the central and local governments in ancient China could not have equal powers and expenditure responsibilities, nor could they have property right matching the power of affairs. Local governments were simply the executors of the central government's decrees. 


\section{Conclusion}

Government finance in ancient China was developed in a long period of autocratic monarchy and highly centralized government. Therefore, government finance in ancient China also had many shackles in exerting the capacity of national governance. For example, the supremacy of the imperial power led to the obvious characteristic of "the rule by man"; the corruption of the feudalistic bureaucratic system led to the implementation deviation of fiscal policy; the thought of "being loyal to the ruler" led to the lack of civic consciousness and the totalitarian system led to the imbalance between intergovernmental relations. Contemporary China should establish a modern fiscal and taxation system that is in line with the requirements of the market economy, as well as establish a systematic, scientific, standardized and effectively operating system, such as an open and transparent budget system, a simple and fair taxation system, an optimized and reasonable system for fiscal expenditure, and a powerful financial supervision and management system. Besides, contemporary China should handle the relations between the central government and local governments properly, as well as the relations between local governments at various levels in order that the administrative powers of governments at all levels are in line with the corresponding expenditure responsibilities. In addition, China should encourage multi subjects to participate in national governance. Particularly, China should cultivate and improve the people's civic consciousness citizenship and sense of entitlement and should increase citizen's participation in the national political life and policy formulation.

\section{References}

[1] GaoPeiyong, 2014. On the Financial Basic Theory Construction under the Framework of Modernization of National Governance. Social Science of China, 12, 102-122.

[2] Li Weiguang, 2014. Why is Finance the Foundation and Pillar of National Governance? Legal Review, 2, 54-60.

[3] Liu Shangxi, 2015. Fiscal and National Governance: Based on Three Dimensions of Understanding. Reference for Economic Research, 38, 3-17.

[4] Liu Xiaolu, Guo Qingwang, 2016. 300 Years of Finance: An Analysis from the Perspective of National Governance. Finance and Trade Economics, 3, 5-13.
[5] Liu Xiaolu, GuoQingwang, 2017. The Change of New China's Fiscal Fundamental Theory from the Perspective of the National Governance. Fiscal Research, 4, 21-27.

[6] BaiYanfeng, Zhang Jing, 2016. NationalGovernance and the Construction of China's Modern Financial System. Journal of Hebei University (Philosophy and Social Sciences Edition), 1, 111-118.

[7] Ma Jun, 2016. The Theory of State Governance in Buchanan's Fiscal Thought. Financial research, 12, 28-37.

[8] Shi Wei, 2015. The "Modernization-like Trap" of Finance and State Governance in Ancient China. Research on Local Finance, 9, 85-90.

[9] Sun Wenxue, Qi Haipeng, 2012. China's Financial History. Northeast University of Finance and Economics Press, Dalian, 18-23.

[10] Xiang Huaicheng, 2006. General History of China's Finance, Second volume. China Financial and Economic Publishing House, Beijing, 89-100.

[11] Sun Yigang, Wang Wensu, 2013. Chinese Financial History. China Social Science Press, Beijing, 25-29.

[12] Ye Zhenpeng, 2013. General History of Chinese Finance. Hunan People's Publishing House, Changsha, 178-191.

[13] Wang Cheng, 2004. Life Cycle of Social Security and Periodic Stage of China. economic research. 3, 98-106.

[14] Zhang Ming, 2016. Discussion on State Governance and Financial Supervision. financial supervision. 6, 34-40.

[15] Liu Xiaocheng, 2007. History of Finance and Taxation in China. China Financial and Economic Publishing House, Beijing, 75-89.

[16] Weng Lihua, 2009. China's Financial History. Economic Science Press, Beijing, 134-150.

[17] Huang Tianhua, 2017. History of China's Financial System, First volume. Shanghai People's Publishing House, Shanghai, 344-356.

[18] Zhang Shoujun, 2003. On Shang Yang's Reform Thought. Journal of Northeast University of Finance and Economics, 4, 94-97.

[19] Liu Shougang, Jia Jie, 2017. A Comparison of Sima Guang's and Wang Anshi's Thoughts on Finance and Governance. Tax research, 5, 118-122. 